\title{
PENGARUH MODEL PEMBELAJARAN MISSOURI MATHEMATICS PROJECT (MMP) TERHADAP KEMAMPUAN PEMECAHAN MASALAH MATEMATIS SISWA KELAS VII SMP NEGERI 4 BALIKPAPAN TAHUN AJARAN 2019/2020
}

\author{
Novita Sari ${ }^{1}$, Rahayu Sri Waskitoningtyas ${ }^{2}$, Ganjar Susilo ${ }^{3}$ \\ Universitas Balikpapan ${ }^{1}$, Universitas Balikpapan ${ }^{2}$, Universitas Balikpapan ${ }^{3}$ \\ pos-el : $\underline{\text { n.sari.010417@gmail.com }}{ }^{1}$, rahayu.sri@uniba-bpn.ac.id ${ }^{2}$, \\ ganjar.susilo@uniba-bpn.ac.id ${ }^{3}$
}

\begin{abstract}
ABSTRAK
Penelitian ini bertujuan untuk mengetahui apakah kemampuan pemecahan masalah matematis siswa yang memperoleh model pembelajaran Missouri Mathematics Project (MMP) lebih baik daripada siswa yang memperoleh model pembelajaran langsung. Penelitian ini dilakukan di SMP Negeri 4 Balikpapan, dengan populasi siswa kelas VII. Teknik pengambilan sampel yang digunakan dalam penelitian ini adalah cluster random sampling. Sampel penelitian ini terdiri dari dua kelas, yaitu kelas VII-2 sebagai kelas eksperimen, yang belajar dengan menggunakan model pembelajaran Missouri Mathematics Project (MMP) dan kelas VII-10 sebagai kelas kontrol, kelas dengan model pembelajaran langsung. Instrumen yang digunakan dalam penelitian ini adalah tes kemampuan pemecahan maslaah matematis sebanyak 6 butir pada pokok bahasan bilangan. Setelah penelitian diperoleh skor rata-rata kelas eksperimen adalah 63,331 dan kelas kontrol 41.503. Analisis data yang digunakan adalah uji normalitas dengan uji Liliefors, uji homogenitas dengan uji levene statistic, uji hipotesis dengan uji-t. Berdasarkan hasil uji hipotesis diperoleh nilai sig $0,000<0,05$ sehingga $\mathrm{H}_{0}$ ditolak. Kesimpulan penelitian ini adalah kemampuan pemecahan masalah matematis siswa yang memperoleh model pembelajaran Missouri Mathematics Project (MMP) lebih baik daripada siswa yang memperoleh model pembelajaran langsung.
\end{abstract}

Kata kunci: model pembelajaran, missouri mathematics project, kemampuan pemecahan masalah matematis

\section{ABSTRACT}

This study aims to determine whether the mathematical problem-solving ability of students who obtain the Missouri Mathematics Project (MMP) learning model is better than students who obtain a direct learning model. This research was conducted at SMP Negeri 4 Balikpapan, with a population of grade VII students. The sampling technique used in this study is cluster random sampling. The research sample consisted of two classes, namely VII-2 class as an experimental class, which learned by using the Missouri Mathematics Project (MMP) learning model and class VII-10 as a control class, a class with a direct learning model. The instrument used in this study was a 6 point mathematical problem-solving ability test on the subject of numbers. After the study was obtained the average score of the experimental class was 63.331 and the control class was 41.503. Data analysis used was a normality test with Liliefors test, homogeneity test with levene statistic, hypothesis test with t-test. Based on the results of the hypothesis test obtained sig value of $0,000<0.05$ so that $H_{0}$ is rejected. The conclusion of this study is the mathematical problem-solving ability of students who get the Missouri Mathematics Project (MMP) learning model better than students who get a direct learning model.

Keywords: learning model, missouri mathematics project, mathematical problem-solving abilities 


\section{PENDAhUluan}

Sekolah merupakan lembaga pendidikan formal yang memberikan siswa kesempatan untuk belajar berbagai macam pelajaran, salah satunya adalah mata pelajaran matematika. KTSP 2006 yang disempurnakan dengan Kurikulum 2013, dimana Kurikulum 2013 memiliki tujuan pembelajaran matematika.

Guru berharap kepada siswa untuk bisa mengerjakan dan memahami soal pemecahan masalah matematis. Pemecahan masalah matematis merupakan suatu hal yang membutuhkan kemampuan khusus dalam menyelesaikannya. Menurut Zahra (2016, p. 65) pemecahan masalah ialah suatu pemikiran yang terarah secara langsung untuk melakukan suatu solusi atau jalan keluar untuk suatu masalah yang spesifik. Penggunaan masalah matematika sangat erat kaitannya dengan kemampuan matematika siswa yang diterapkan dalam kehidupan nyata. Kemampuan tersebut membutuhkan latihan dan penyesuaian yang memerlukan waktu yang tidak singkat.

Berdasarkan hasil pengamatan dan wawancara dengan guru di SMP Negeri 4 Balikpapan didapatkan informasi tentang pembelajaran matematika. Dimana aktifitas yang terjadi selama pembelajaran matematika cenderung berlangsung satu arah yaitu dari guru ke siswa sehingga siswa lebih berperan sebagai penerima ilmu. Serta aktivitas siswa di kelas kurang menuntut siswa untuk berkomunikasi dan berinteraksi antar siswa. Selanjutnya masalah lain seperti tingkat kemampuan matematis siswa masih tergolong lemah. Salah satu dari kemampuan tersebut adalah kemampuan pemecahan masalah. Guru menyebutkan bahwa kemampuan pemecahan masalah matematis siswa masih tergolong rendah. Sedangkan penggunaan masalah matematika sangat erat kaitannya dengan kemampuan matematika siswa yang dapat diterapkan dalam kehidupan nyata (Rohman, Yuniarti, \& Permatasari, 2018). Berdasarkan hal tersebut maka kemampuan pemecahan masalah penting dimiliki oleh siswa. Terdapat beberapa faktor dari dalam maupun luar diri siswa yang mempengaruhi kemampuan pemecahan masalah siswa (Waskitoningtyas, 2017). Salah satu yang dapat mempengaruhi siswa yang berasal dari luar adalah penggunaan metode pembelajaran oleh guru.

Selain itu, guru menjelaskan bahwa siswa mengalami kesulitan dalam mengerjakan soal-soal yang berbentuk soal cerita. Hal tersebut ditunjukan dengan sebagian besar siswa yang mengeluh ketika dihadapkan dengan soal cerita. Selain itu, siswa juga kurang cermat dalam membaca dan memahami kalimat dari suatu soal cerita dan siswa sulit menentukan konsep matematika atau rumus yang tepat. Ada juga siswa yang dapat menentukan rumus namun tidak dapat menentukan strategi dalam menyelesaikan soal.

Salah satu alternatif model pembelajaran yang mampu menempatkan siswa pada posisi yang lebih aktif dan kreatif, serta dapat memberikan banyak latihan soal pada siswa guna meningkatkan kemampuan pemecahan masalah matematis siswa adalah model pembelajaran Missouri Mathematics Project (MMP). Wahyuni \& Efuansyah (2018, p. 25) menyatakan bahwa model MMP dapat meningkatkan keterampilan siswa 
dalam mengerjakan soal matematika dengan latihan terkontrol dan latihan mandiri. Ansori \& Aulia (2015, p. 50) menyatakan bahwa model pembelajaran MMP merupakan suatu program yang didesain untuk membantu guru dalam hal efektivitas penggunaan latihanlatihan agar siswa mencapai peningkatan yang luar biasa. Melalui efektivitas penggunaan latihan-latihan tersebut diharapkan siswa terbiasa menyelesaikan permasalahanpermasalahan matematika

Berdasarkan pemilihan model tersebut, penelitian ini didukung oleh penelitian yang relevan, yaitu: penelitian yang dilakukan oleh Ansori \& Aulia (2015, p. 57) menyatakan bahwa model pembelajaran Missouri Mathematics Project (MMP) dapat meningkatkan kemampuan pemecahan masalah siswa dalam pembelajaran matematika. Sedangkan penelitian Fauziah \& Sukasno (2015, p. 19) menyatakan bahwa terdapat pengaruh model Missouri Mathematics Project (MMP) terhadap kemampuan pemecahan masalah matematika siswa. Rendahnya hasil belajar matematika siswa dikarenakan kemandirian belajar dan kecerdasan interpersonal siswa yang belum baik pada saat proses pembelajaran, hal ini sejalan dengan penelitian yang pernah dilakukan oleh Sufatihah (2018, p. 175) menunjukkan bahwa terdapat pengaruh yang signifikan motivasi berprestasi dan kemandirian belajar terhadap prestasi belajar matematika. Penelitian selanjutnya, dilakukan oleh Najamuddin, Idris, \& Afif (2015, p. 174) menunjukkan bahwa terdapat pengaruh antara kecerdasan interpersonal dan task commitment terhadap hasil belajar matematika siswa.
Berdasarkan latar belakang yang telah diuraikan peneliti akan melakukan penelitian tentang pengaruh model pembelajaran Missouri Mathematics Project (MMP) terhadap kemampuan pemecahan masalah matematis siswa kelas VII SMP Negeri 4 Balikpapan Tahun Ajaran 2019/2020.

\section{METODE PENELITIAN}

Penelitian ini menggunakan pendekatan kuantitatif dengan jenis penelitian quasi eksperimen. Penelitian ini dilaksanakan di SMP Negeri 4 Balikpapan pada kelas VII dengan jumlah sampel sebesar 422 siswa. Teknik pengambilan sampel menggunakan cluster random sampling. Instrumen pengumpulan data yang digunakan pada penelitian ini adalah tes yang berbentuk uraian. Sebelum digunakan instrumen tes maka terlebih dahulu diuji cobakan untuk mengetahui validitas, reliabilitas tes, insdeks kesukaran soal dan daya pembedanya. Berdasarkan hasil uji intrumen tersebut ke enam soal dapat digunakan untuk mengukur kemampuan pemecahan masalah matematis siswa.

Teknik analisis data pada penelitian ini adalah dilakukan uji normalitas. Uji normalitas digunakan untuk mengetahui kelas eksperimen dan kelas kontrol sebelum diberikan perlakuan apakah berdistribusi normal atau tidak. Uji yang digunakan adalah uji Lilliefors dengan prosedur uji menggunakan SPSS 20.0

Uji homogenitas dilakukan untuk mengetahui apakah kelompok eksperimen dan kontrol memiliki varian yang sama (homogen). Rumus yang digunakan dalam uji homogenitas 
adalah uji levene statistic, karena menguji dua kelompok data.

Uji hipotesis dilakukan untuk mengetahui tujuan utama dari penelitian eksperimen ini dilakukan, apakah terdapat perbedaan antara kelas eksperimen dan kelas kontrol terhadap kemampuan pemecahan masalah matematis siswa yang diberikan model pembelajaran Missouri Mathematics Project (MMP) dengan siswa yang tidak diberikan model pembelajaran Missouri Mathematics Project (MMP). Statistik uji yang digunakan adalah ujit.

\section{HASIL DAN PEMBAHASAN}

\section{A. Hasil Penelitian}

Data hasil penelitian yang diperoleh berupa data hasil posttest yang diberikan kepada siswa kemudian di analisis. Berdasarkan hasil posttest yang diberikan kepada siswa, maka diperoleh dua kelompok nilai yaitu nilai kelas eksperimen yang memperoleh model pembelajaran Missouri Mathematics Project (MMP) dan nilai kelas kontrol yang memperoleh model pembelajaran langsung. Berikut uraian data hasil posttest pada masing-masing kelas.

\begin{tabular}{|l|c|c|}
\hline $\begin{array}{c}\text { Distribusi } \\
\text { Frekuensi }\end{array}$ & $\begin{array}{c}\text { Kelas } \\
\text { Eksperimen }\end{array}$ & $\begin{array}{c}\text { Kelas } \\
\text { Kontrol }\end{array}$ \\
\hline Jumlah Siswa & 39 & 38 \\
\hline KKM & 72 & 72 \\
\hline Nilai Tertinggi & 85,40 & 64,10 \\
\hline Nilai Terendah & 29,10 & 12,50 \\
\hline Nilai Ideal & 100 & 100 \\
\hline Rata-rata & 63,33 & 41,50 \\
\hline $\begin{array}{l}\text { Simpangan } \\
\text { Baku }\end{array}$ & 13,49 & 12,41 \\
\hline Variansi & 182,12 & 154,04 \\
\hline
\end{tabular}

Berdasarkan tabel di atas, diperoleh hasil posttest kemampuan pemecahan masalah matematis siswa yang diberikan kepada kedua kelas dengan jumlah siswa kelas eksperimen 39 siswa dan kelas kontrol 38 siswa, diperoleh rata-rata sebesar 63,33 untuk kelas eksperimen dengan simpangan baku sebesar 13,49 dan 41,50 untuk kelas kontrol dengan simpangan baku sebesar 12,41.

\section{1) Hasil Uji Prasyarat}

a. Uji Normalitas

Hasil uji normalitas posttest kelas eksperimen diperoleh nilai Sig $=0,17$, dengan demikian $\mathrm{H}_{0}$ diterima. Untuk kelas kontrol diperoleh nilai $\mathrm{Sig} .=0,05$ sehingga $\mathrm{H}_{0}$ diterima. Maka dapat disimpulkan bahwa kedua kelas yaitu, kelas eksperimen dan kelas kontrol berasal dari sampel berdistribusi normal.

\section{b. Uji Homogenitas}

Setelah dilakukan uji normalitas, kemudian dilakukan uji homogenitas varians pada hasil posttest kemampuan pemecahan masalah matematis. Hasil uji homogenitas menggunakan metode levene statistic diperoleh nilai Sig. $=0,92$. Dengan demikian $0,92 \geq$ 0,05. Maka dapat disimpulkan bahwa hasil posttest kemampuan pemecahan masalah matematis pada kedua kelompok yaitu, kelas eksperimen dan kelas kontrol memiliki variansi yang sama.

\section{2) Hasil Uji Hipotesis}

Setelah diberikan perlakuan kepada sampel, maka dilaksanakan posttest, dari posttest ini diperoleh data yang dipergunakan sebagai dasar perhitungan uji hipotesis. Uji hipotesis yang digunakan dalam penelitian ini adalah uji Independent Sample T-test. 
hasil uji hipotesis nilai Sig. (2-tailed) 0,00. Dimana nilai $0,00<0,05$, dapat disimpulkan bahwa $\mathrm{H}_{0}$ ditolak, yaitu kemampuan pemecahan masalah matematis siswa yang menggunakan model pembelajaran Missouri Mathematics Project (MMP) lebih baik dari pada kemampuan pemecahan masalah matematis siswa yang menggunakan model pembelajaran langsung.

\section{B. Pembahasan}

Hasil uji hipotesis pada skor posttest kemampuan pemecahan masalah matematis menunjukkan bahwa kemampuan pemecahan masalah matematis siswa yang menggunakan model pembelajaran Missouri Mathematics Project (MMP) lebih baik dari pada kemampuan pemecahan masalah matematis siswa yang menggunakan pembelajaran konvensional.

Hal ini terjadi karena salah satu bentuk kegiatan yang terdapat pada model pembelajaran Missouri Mathematics Project (MMP) seat work/kerja mandiri, dimana dalam kegiatan ini dapat melatih tanggung jawab siswa dalam mengerjakan soal secara mandiri dan siswa dapat melatih kemampuannya secara mandiri untuk memahami permasalahan yang disajikan. Hal tersebut sesuai dengan pendapat Sari (2016, p. 33) yang mengungkapkan bahwa dengan adanya tugas individu, dapat meningkatkan tanggung jawab siswa terhadap kemampuan individu dalam menyelesaikan permasalahan yang disajikan.

Selain seat work/kerja mandiri terdapat bentuk kegiatan lain dalam sintaks model pembelajaran Missouri Mathematics Project (MMP) yang menunjang siswa dalam meningkatkan kemampuan pemecahan masalah matematis, yaitu kegiatan siswa dalam berdiskusi dengan kelompok belajarnya. Diskusi merupakan kegiatan yang dilakukan siswa saat mengerjakan lembar aktivitas siswa (LAS). Kegiatan diskusi sebagai sarana siswa untuk dapat berkomunikasi dengan baik antar anggota kelompok belajarnya maupun dengan guru. Hal tersebut sesuai dengan pendapat Ansori \& Aulia (2015, p. 51) mengungkapkan bahwa dengan berdiskusi siswa dapat mempercepat kemampuan pemecahan masalah matematis melalui keterampilan berkomunikasi untuk mengungkapkan idenya dalam menyelesaikan masalah.

Pada model pembelajaran Missouri Mathematics Project (MMP) terlihat bahwa model tersebut dapat menjadikan siswa aktif mengerjakan soal atau permasalahan matematika yang diberikan oleh guru. Hal tersebut sesuai dengan pendapat Hidayah \& Ulya (2016, p. 180) yang mengungkapkan bahwa dengan model pembelajaran Missouri Mathematics Project (MMP) siswa dapat melatih kemampuan pemecahan masalah matematisnya dengan pembelajaran yang terstruktur.

Lain halnya dengan pembelajaran langsung, proses pemahaman yang terjadi pada siswa hanya terjadi pada satu arah dan sangat bergantung pada guru. Sehingga banyak siswa yang merasa bosan, kurang aktif dan hanya sedikit yang memperhatikan guru. Siswa merasa kesulitan dalam mengkomunikasikan ide maupun gagasannya karena siswa hanya memiliki sedikit kesempatan untuk terlibat secara aktif. Siswa akan mudah kehilangan perhatian dan hanya akan mengingat sebagian kecil isi materi yang disampaikan. Hal tersebut sesuai dengan pendapat Wilanda \& Supriyono (2014, p. 4) bahwa ciri khas dalam pembelajaran konvensional lebih mengarah pada penyelesaian soal-soal latihan yang sebelum diberikan dijelaskan oleh guru melalui contoh, 
sehingga pada akhirnya siswa jarang bertanya dan guru sulit untuk mengetahui tingkat pemahaman siswa, terlebih yang sering dilakukan siswa hanyalah mencatat ataupun menyalin. Maka, akibatnya kemampuan kognitif siswa sangat lemah dalam proses pembelajaran tersebut.

Berdasarkan pemaparan yang telah disampaikan di atas, setelah model pembelajaran Missouri Mathematics Project (MMP) digunakan dalam pembelajaran matematika, terlihat bahwa kemampuan pemahaman matematis siswa pada kelas eksperimen lebih baik dari pada kemampuan pemahaman matematis siswa pada kelas kontrol. Hal ini terjadi karena siswa yang memperoleh model pembelajaran MMP menjadi lebih aktif dan terbiasa dalam mengerjakan soal pemecahan masalah. Berdasarkan hasil uji hipotesis nilai sig $<0,05$ maka $\mathrm{H}_{0}$ ditolak. Maka dapat disimpulkan bahwa kemampuan pemecahan masalah matematis siswa yang memperoleh model pembelajaran Missouri Mathematics Project lebih baik dari pada siswa yang memperoleh model pembelajaran langsung.

\section{KESIMPULAN}

Berdasarkan pengolahan dan analisis data yang telah dilakukan, maka dapat disimpulkan bahwa kemampuan pemecahan masalah matematis siswa yang memperoleh model pembelajaran Missouri Mathematics Project (MMP) lebih baik dari pada siswa yang memperoleh model pembelajaran langsung.

\section{DAFTAR PUSTAKA}

Ansori, H., \& Aulia, I. (2015). Penerapan Model Pembelajaran Missouri Mathematics Project (MMP) Terhadap Kemampuan Pemecahan Masalah Siswa di SMP. Jurnal Pendidikan Matematika, III(1), 49-58. Retrieved from http://ppjp.unlam.ac.id/journal/inde x.php/edumat/article/view/629

Fauziah, A., \& Sukasno, S. (2015).

Pengaruh Model Missouri

Mathematics Project (MMP)

Terhadap Kemampuan

Pemahaman Dan Pemecahan

Masalah Matematika Siswa Sma N

I Lubuklinggau. Journal Ilmiah, IV(1), 10-21. https://doi.org/10.22460/infinity.v4 i1.67

Hidayah, I., \& Ulya, R. (2016). Kemampuan Pemecahan Masalah Ditinjau Dari Self-Efficacy Siswa Dalam Model Pembelajaran Missouri Mathematics Project. Journal of Mathematics Education, $V(2)$, 178-183. Retrieved from https://journal.unnes.ac.id/sju/inde x.php/ujmer/article/view/12934

Najamuddin, Idris, R., \& Afif, A. (2015). Pengaruh Kecerdasan Interpersonal dan Taks Commiment Terhadap Hasil Belajar Matematika Siswa Kelas VIII MTs Negeri Balang-Balang Kabupaten Gowa. Jurnal Matematika Dan Pembelajaran, III(2), 163-176. Retrieved from http://journal.uin-

alauddin.ac.id/index.php/Mapan/ar ticle/view/3887/3539

Rohman, A. A., Yuniarti, S., \& Permatasari, B. I. (2018). Pengaruh Metakognisi dan Kreativitas Terhadap Kemempuan Pemecahan Masalah Matematis Siswa Kelas X IPS SMA Negeri 4 Balikpapan Tahun Ajaran 2017/2018. de Fermat: Jurnal Pendidikan Matematika, 1(2), 85-90.

Sari, T. H. N. I. (2016). Pengaruh Model Pembelajaran Missouri Mathematics Project (MMP) Terhadap Kemampuan Pembuktian Matematis Siswa SMP. Jurnal Ilmiah Pendidikan Matematika, 
III(2), 22-35. Retrieved from https://ejournal.stkipbbm.ac.id

Sufatihah, I. (2018). Pengaruh Motivasi Berprestasi dan Kemandirian Belajar Terhadap Prestasi Belajar Matematika. Jurnal Kajian Pendidikan Matematika, III(2), 157-164. Retrieved from https://journal.lppmunindra.ac.id/in dex.php/jkpm/article/view/2770/22 10

Wahyuni, R., \& Efuansyah. (2018). Model Pembelajaran Missouri Mathematics Project ( Mmp ) Menggunakan Strategi Think Talk Write ( Ttw ) Terhadap Kemampuan Berpikir Kritis Dan Kemampuan Pemecahan Masalah. Jurnal Nasional Pendidikan Matematika, II(1), 24-36.
Retrieved from http://jurnal.unswagati.ac.id/index. php/JNPM/article/view/778

Wilanda, R. A., \& Supriyono. (2014). Penerapan Model Pembelajaran Langsung Untuk Meningkatkan Hasil Belajar Pada Tema Peristiwa Belajar Di Sekolah. Jurnal Mahasiswa, II(3), 1-10. Retrieved from

http://jurnalmahasiswa.unesa.ac.id

Waskitoningtyas, R. S. (2017). Pengaruh Gaya Belajar Terhadap Kemampuan Pemecahan Masalah Mahasiswa Calon Guru Matematika. Magistra, 36-43.

Zahra, C. (2016). Metakognisi Siswa Dalam Pemecahan Masalah Matematika. Yogyakarta: Deepublish. 